\title{
KONSEP DAN PENGUNAAN WARNA DALAM INFOGRAFIS
}

\author{
Ariefika Listya \\ Program Studi Desain Komunikasi Visual, \\ Fakultas Bahasa dan Seni Universitas Indraprasta PGRI
}

\begin{abstract}
Abstrak
Fenomena media infografis dalam dunia digital yang sedang marak ini cukup menarik perhatian untuk diteliti lebih lanjut. Infografis saat ini dipilih sebagai media publikasi informasi dari suatu instansi baik laporan hasil penelitian pemerintah maupun swasta sampai dengan iklan komersial dari berbagai brand. Penelitian ini menggunakan metode kualitatif deskriptif dengan pendekatan estetika yang menganalisis aspek formalistik khususnya warna. Data diperoleh dari literatur yang berkaitan dengan warna dan media infografis serta observasi dengan mengamati 20 media infografis yang berbeda yang diunduh dari internet. Hasil penelitian menunjukkan warna berperan penting dalam pertimbangan konseptual terkait apa konten dan temanya, siapa target audiennya, dan apa kesan dan identitas yang ingin ditampilkan dalam perancangan media infografis. Penggunaan warna juga cukup vital dalam media infografis mencakup menciptakan keberbedaan antar konten dan kategori, menciptakan kesatuan, memberikan penekanan pada konten tertentu yang ingin ditonjolkan, dan menciptakan kontras antara figure dengan ground sehingga pesan dalam infografis dapat dengan mudah dimengerti oleh target audiens.
\end{abstract}

Kata Kunci: konsep, penggunaan, warna, media, infografis

\begin{abstract}
The phenomenon of infographic media in the emerging digital world is enough to gain attention for further research. Infographic is used as a media for publishing information from research report of institutions to commercial advertisement of various brands. This research uses descriptive qualitative method with an aesthetic approach that analyzes the formalistic aspects specifically color. Data obtained from literature related to colors and infographic, and observation by watching 20 different infographic medias downloaded from the internet. The results showed that color has an important role in the conceptual consideration related to what are the content and themes, who are the target audiences, and what is the desired image and identity should be reperesented in infographics. The usages of color is also quite important in infographic media to creating differences between contents and categories, creating unity, giving an impression on the highlighted content, and creating a contrast between figure and ground so that its messages are easy to understand by the target audience.
\end{abstract}

Keywords: Concepts, usages, color, media, infographic

\section{PENDAHULUAN}

Warna telah menjadi objek pe-nelitian oleh para ahli di berbagai bidang, beberapa diantaranya fisika, kedokteran, psikologi, pemasaran dan juga desain. Hasil penelitian menunjukkan bahwa warna dapat mempengaruhi mood se-seorang, sampai dengan mempengaruhi keputusan pembelian. Begitu banyak peran warna dalam kehidupan manusia menjadikan warna objek studi yang masih diteliti hingga sekarang. Dalam ilmu desain komunikasi visual, warna adalah salah satu elemen desain yang krusial.

Warna telah lebih dulu dipersepsi-kan sebelum bentuk dikenali sehingga dapat dikatakan warna adalah elemen wajib dalam desain, karena tanpa warna maka elemen lainnya dapat dikatakan tidak ada. 
Dalam dunia digital, dikenal media infografis yang menginformasikan data baik kualitatif maupun kuantitatif melalui visual yang atraktif. Infografis di Indonesia saat ini masih digunakan dan berkembang, seiring dengan pesatnya perkembangan teknologi informasi dan penggunaan gadget. Hasil survey di tahun 2017 oleh Asosiasi Penyelenggara Jasa Internet Indonesia (APJII) mem-buktikan bahwa hampir separuh lebih penduduk Indonesia dalam juta jiwa menggunakan internet. Adanya koneksi internet menyebabkan akses terhadap media infografis pun mudah dibanding media lainnya. Terlebih, infografis yang bersifat dinamis atau bergerak disajikan dalam audio visual. Infografis saat ini dipilih sebagai media publikasi informasi dari suatu instansi baik kepemerintahan maupun swasta sampai dengan iklan komersial dari berbagai brand. Sebagai bagian dari tim pengajar mata kuliah Desain Infografis pada program studi Desain Komunikasi Visual, peneliti mengamati kemenarikan fenomena desain dalam media Infografis dinamis (infografis bergerak) khususnya elemen warna yang akan dipaparkan dalam artikel ilmiah ini. Konsep dan penggunaan warna khususnya dalam media infografis penting untuk diteliti karena nampaknya akan berdampak pada keberhasilan komunikasi dalam menyampaikan informasi dan pesan melalui media tersebut.

\section{METODE PENELITIAN}

Penelitian ini menggunakan metode kualitatif deskriptif dengan teknik pengumpulan data literatur dan observasi. Pendekatan penelitian dengan estetika terapan akan dapat mengungkap warna terkait konsep dan penggunaan-nya. Sumber data primernya adalah hasil pengamatan terhadap 20 infografis dinamis/ bergerak yang bervariatif yang diunduh dari laman website Youtube. Pengumpulan data dilakukan melalui pencarian literatur berupa buku dan jurnal ilmiah mengenai infografis dan warna.

Pemilihan infografis didasari atas adanya keberbedaan antar infografis. Pertama, 20 infografis tersebut berkaitan dengan berbagai instansi yakni pemerintah, BUMN sampai dengan perusahaan swasta dan juga brand suatu produk. Kedua, dari sisi konten, infografis yang dipilih sebagian berisi informasi dan atau persuasi promosi dan atau berisi kampanye perubahan sosial. Ketiga, dari sisi objek dan tema yang berbeda-beda. Terakhir yaitu yang keempat, dari sisi konsep dan peng-gunaan warnanya bervariasi.

Studi ini dibatasi pada Konsep dan penggunaan warna dalam media infografis. Konsep dan penggunaan warna adalah hal yang berbeda. Konsep yang dimaksud dalam judul artikel ilmiah ini adalah pemikiran terhadap pemilihan warna yang melandasi perancangan mencakup salah satunya makna filosofis warna. Penggunaan yang dimaksud ialah implementasi dari konsep yang lebih bersifat kearah teknis dan secara fisik termasuk diantaranya adanya kontras warna.

\section{HASIL DAN PEMBAHASAN}

\section{Karakteristik Media Infografis}

Infografis dapat diartikan sebagai representasi visual dari informasi, data atau pengetahuan yang menggabungkan data dan desain dengan lebih baik daripada data yang terdiri dari teks saja (Lee, 2014: 129). Saptodewo (2014: 198) juga sependapat mengenai aspek visual yang berperan penting dalam infografis dalam menyajikan data, informasi dan pengetahuan yang bukan hanya sekedar teks semata. Sejalan dengan pernyataan Lee dan Saptodewo, kemudian Lankow, Ritchie dan Crooks (2014: 12) mengata-kan bahwa infografis disebut sebagai sebuah visualisasi data, informasi, atau struktur informasi. Informasi yang disajikan dengan gambar lebih baik dibandingkan dengan teks. Orang akan jauh lebih cepat memproses 
informasi yang disampaikan dengan gambar secara sekaligus oleh otak, sedangkan informasi yang disampaikan dengan teks akan diproses secara linear. Tujuan infografis dapat dikategorikan ke dalam tiga tujuan komunikasi ke khalayak (Dur, 2014: 43) yaitu untuk menginformasikan, meng-hibur, atau membujuk audiens. Infografis memiliki cara untuk mengenalkan dan mendapatkan perhatian audiens, jadi para audiens tahu mengapa harus meluangkan waktu untuk membaca infografis.

Tiga aspek penting dalam infografis (Lankow, dkk., 2014: 40) adalah daya pikat, komprehensi dan retensi. Daya pikat merupakan aspek yang dapat membuat khalayak tertarik untuk melihat sebuah infografis dalam waktu yang cukup lama sehingga pesan dalam infografis dapat tersampaikan. Daya pikat dapat diciptakan melalui rancangan visual dengan menggunakan ikon-ikon sederhana yang unik, tata letak elemen-elemen desain yang sedemikian rupa dan pemilihan warna-warna yang enak dipandang sehingga menimbulkan ketertarikan khalayak untuk mengetahui lebih lanjut apa isi dari infografis ter-sebut.

Aspek lainnya ialah komprehensi (pemahaman), yang merupakan respon audiens saat melihat sebuah infografis pertama kali. Dalam merancang infografis bukan hanya bagaimana membuat menjadi menarik, melainkan juga harus memikirkan pesan infografis agar bisa dipahami audiens. Ada infografis yang menarik namun sulit untuk dipahami, sehingga berdampak pesan dalam infografis tak tersampaikan dengan baik dan juga efektif. Peranan gaya komunikasi verbal seperti misalnya pemilihan kata dalam infografis perlu diperhatikan dan dibuat sesuai target audiens yang dituju. tidak hanya. Narasi dan penggambaran ikon dalam infografis juga perlu disesuaikan dengan isi infografis dan hasil analisis khalayak. Aspek terakhir yakni retensi, yaitu visualisasi yang membantu audiens mengingat informasi yang disampaikan dalam media infografis (Lankow, dkk., 2014: 44-45). Nampaknya konsep komunikasi AIDA (Attention Interest Desire Action) dapat terpenuhi dengan baik dengan ketiga aspek penting dalam infografis.

Telah disebutkan bahwa elemen desain pada media infografis salah satunya warna. Dalam usaha memenuhi tiga aspek penting pada infografis, warna berperan penting untuk daya pikat, komprehensi dan retensi. Sehubungan dengan aspek daya tarik telah dijelaskan sebelumnya bahwa warna dapat me-nimbulkan ketertarikan. Aspek komprehensi (memahami) dan retensi (mengingat) dapat dicapai dengan peng-gunaan warna-warna yang sesuai dengan aslinya, warna yang membedakan satu hal dengan yang lainnya, kombinasi warna kontras, maupun warna yang menekankan pada bagian tertentu. Warna adalah faktor yang terpenting dalam komunikasi visual karena warna mem-berikan kesan secara psikologis, sugesti maupun suasana (Soewignjo, 2013: 2). Soewignjo (2013: 43) juga menyatakan bahwa pemilihan kombinasi warna yang baik akan memberi efek yang juga baik. Dalam penelitiannya terhadap visual infografis suatu produk, Arifianto menyatakan bahwa dominasi warna sebagai latar belakang memberi sebuah makna tertentu (2018: 126).

\section{Hasil analisis terkait warna pada 20 infografis}

Berikut ini adalah daftar 20 infografis yang diamati:

Tabel 1

\begin{tabular}{|c|c|c|c|c|}
\hline No & $\begin{array}{l}\text { Judul/tema } \\
\text { Infografis }\end{array}$ & $\begin{array}{l}\text { Screenshot } \\
\text { contoh tampilan } \\
\text { Frame }\end{array}$ & $\begin{array}{l}\text { Pembuat/ } \\
\text { Komunikator }\end{array}$ & Sifat pesan \\
\hline
\end{tabular}




\begin{tabular}{|c|c|c|c|c|}
\hline 1 & $\begin{array}{l}\text { Transportasi Umum } \\
\text { Jakarta dari Masa ke } \\
\text { Masa }\end{array}$ & 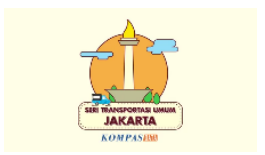 & Kompas & informasi \\
\hline 2 & $\begin{array}{l}\text { Cara Bikin Kamu } \\
\text { Tumbuh Tinggi }\end{array}$ & Hilo & Hilo Teen & $\begin{array}{l}\text { Informasi dan } \\
\text { persuasi } \\
\text { promosi }\end{array}$ \\
\hline 3 & $\begin{array}{l}\text { Kesiapsiagaan } \\
\text { Bencana Gempa } \\
\text { Bumi }\end{array}$ & (xine & $\begin{array}{l}\text { Kementrian } \\
\text { Kesehatan RI }\end{array}$ & informasi \\
\hline 4 & $\begin{array}{l}\text { Kebutuhan Satelit } \\
\text { untuk Indonesia }\end{array}$ & 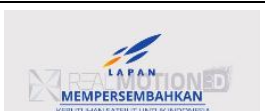 & LAPAN & informasi \\
\hline 5 & $\begin{array}{l}\text { Fakta-fakta Seputra } \\
\text { Narkoba }\end{array}$ & $\begin{array}{l}\text { FAKTA-FAKTA } \\
\text { NARPRAROBA }\end{array}$ & Metro TV & $\begin{array}{l}\text { Informasi dan } \\
\text { kampanye } \\
\text { perubahan } \\
\text { sosial } \\
\end{array}$ \\
\hline 6 & Global Air Traffic & $\operatorname{man} 20$ & $\begin{array}{l}\text { Rightcolours.c } \\
\text { om }\end{array}$ & Informasi \\
\hline 7 & $\begin{array}{l}\text { Indonesia dalam } \\
\text { Angka \#video }\end{array}$ & $\begin{array}{l}\text { INDONESIA } \\
\text { OANGKA } \\
\text { ANGEA } \\
\text { AVIDEO }\end{array}$ & $\begin{array}{l}\text { Numberwan } \\
\text { Channel }\end{array}$ & Informasi \\
\hline 8 & Wood naturally & & $\begin{array}{l}\text { Woodnaturally } \\
\text {.com }\end{array}$ & $\begin{array}{l}\text { Informasi dan } \\
\text { persuasi } \\
\text { promosi }\end{array}$ \\
\hline 9 & $\begin{array}{l}\text { The Future of } \\
\text { Marketing }\end{array}$ & 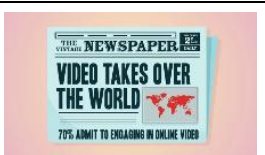 & Istock & Informasi \\
\hline 10 & Apa Itu PPAM & & $\begin{array}{l}\text { Kementrian } \\
\text { Kesehatan RI } \\
\text { dan UNFPA }\end{array}$ & Informasi \\
\hline 11 & $\begin{array}{l}\text { Paper to Save } \\
\text { Forests }\end{array}$ & rishet & Cheil India & $\begin{array}{l}\text { Informasi dan } \\
\text { kampanye } \\
\text { perubahan } \\
\text { sosial }\end{array}$ \\
\hline 12 & $\begin{array}{lr}\text { Mengenal } & \text { Industri } \\
\text { Hulu } & \text { Migas } \\
\text { Indonesia } & \end{array}$ & & SKK Migas & Informasi \\
\hline 13 & Bareksa & $\begin{array}{c}\text { MekaunG } \\
\text { KAYA } \\
-9\end{array}$ & Bareksa.com & $\begin{array}{l}\text { Informasi dan } \\
\text { persuasi } \\
\text { promosi }\end{array}$ \\
\hline
\end{tabular}




\begin{tabular}{|c|c|c|c|c|}
\hline 14 & $\begin{array}{l}\text { Lawan } \quad \text { Korupsi } \\
2014\end{array}$ & 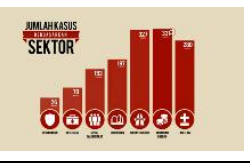 & $\begin{array}{l}\text { Indonesia } \\
\text { Corruption } \\
\text { Watch }\end{array}$ & Informasi \\
\hline 15 & $\begin{array}{l}\text { Infografis LPG } \\
\text { Rumah Tangga }\end{array}$ & $\Rightarrow 8$ & Pertamina & $\begin{array}{l}\text { Informasi dan } \\
\text { persuasi } \\
\text { promosi }\end{array}$ \\
\hline 16 & $\begin{array}{l}\text { The Global Water } \\
\text { Crisis }\end{array}$ & & Takepart.com & $\begin{array}{l}\text { Informasi dan } \\
\text { kampanye } \\
\text { perubahan } \\
\text { sosial }\end{array}$ \\
\hline 17 & $\begin{array}{l}\text { Infografis PT } \\
\text { Kereta Api } \\
\text { Indonesia Produksi } \\
\text { PFN }\end{array}$ & $\begin{array}{l}384.3 \\
2016 \\
2 A R G E\end{array}$ & $\begin{array}{l}\text { PT. KAI dan } \\
\text { PFN }\end{array}$ & Informasi \\
\hline 18 & $\begin{array}{l}\text { Infografis Subsidi } \\
\text { Listrik }\end{array}$ & 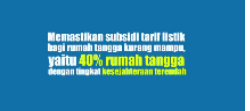 & $\begin{array}{l}\text { Kominfo dan } \\
\text { Octacube }\end{array}$ & Informasi \\
\hline 19 & $\begin{array}{l}\text { Shigella Medical } \\
\text { Animation }\end{array}$ & & $\begin{array}{l}\text { Marler Clark - } \\
\text { The Food } \\
\text { Safety law } \\
\text { Firm }\end{array}$ & Informasi \\
\hline 20 & $\begin{array}{l}\text { Ini Penyebab } \\
\text { Durasi Puasa } \\
\text { Berbeda-beda di } \\
\text { Tiap Negara }\end{array}$ & DURASI PUASA & Kompas & Informasi \\
\hline
\end{tabular}

Konsep dan penggunaan warna yang hampir selalu ada dalam semua infografis yang diamati ialah warna sebagai asosiasi alamiah, dimana figure (objek) dan ground (latar belakang) digambarkan dengan warna yang mirip sesuai dengan warna aslinya, seperti contohnya pada gambar 1 di bawah ini:

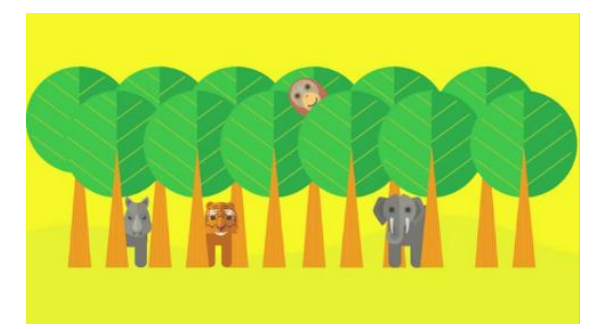

Gambar 1 frame pada Infografis berjudul Apa itu PPAM

(sumber: https://www.youtube.com/watch?v=zH_sbbL7dws diakses pada 15 Agustus 2018)

Infografis pada umumnya meng-gunakan gaya flat design dimana warna-nya solid merata, tidak bergradasi. Peng-gambaran bayangannya pun solid, dengan perbedaan warna terang gelap dari suatu warna. Pada gambar 1 diatas misalnya, untuk menggambarkan kumpulan dedaunan pohon maka warna yang digunakan adalah hijau terang dan hijau gelap yang seakan dibatasi garis nyata akibat perbedaan nilai warnanya. 
Infografis di bawah ini menampil-kan dominasi warna hijau untuk meng-asosiasikannya dengan hutan dan warna putih untuk mengasosiasikannya dengan kertas dalam kampanye perubahan sosial:
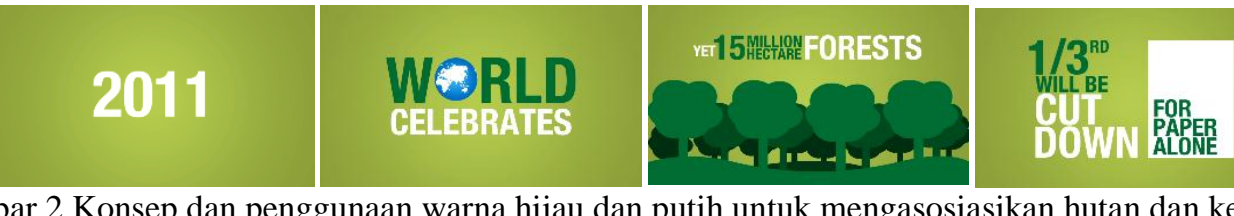

Gambar 2 Konsep dan penggunaan warna hijau dan putih untuk mengasosiasikan hutan dan kertas pada Infografis Paper to Save Forests oleh Cheil India (sumber: https://www.youtube.com/ watch?v=jHQGyMBtE9Y diakses pada 15 Agustus 2018)

Warna dalam media infografis ternyata tidak hanya digunakan sesuai warna alamiah suatu objek, namun juga sebagai simbol. Infografis oleh Kompas Data pada gambar 3 dibawah ini bernuansa hijau. Infografis ini juga menggunakan pemandangan landmark di berbagai negara yang disajikan lewat foto namun tone warnanya diganti menjadi kehijauan, sesuai dengan simbol warna pada islam karena informasinya berkaitan dengan puasa:
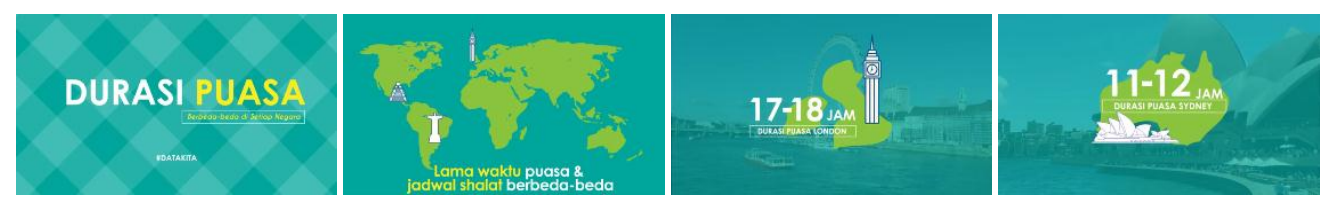

Gambar 3 Konsep dan penggunaan warna hijau untuk menyimbolkan sesuatu pada Infografis berjudul Penyebab Durasi Puasa Berbeda-beda Tiap Negara oleh Kompas Data

(sumber: https://www.youtube.com/watch?v=Nn62pyEXx5g, diakses pada 15 Agustus 2018)

Melalui infografis berjudul Penyebab Durasi Puasa Berbeda-beda Tiap Negara oleh Kompas Data diatas, dapat disimpulkan bahwa konsep warna untuk suatu tema tertentu dapat menggunakan dominasi warna yang berasosiasi dengan temanya, bahkan satu warna saja misalkan hijau dengan kombinasi terang gelapnya.

Warna juga bisa dikaitkan dengan identitas tertentu seperti misalnya dalam bagian pembuka dan bagian penutup infografis Kompas pada gambar 4 di bawah ini:

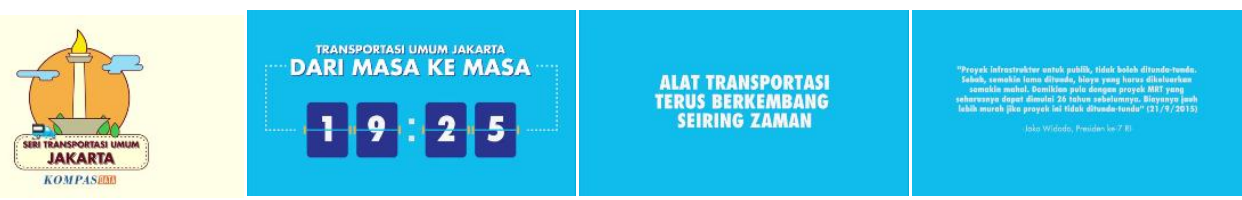

Gambar 4 konsep dan penggunaan warna biru sebagai identitas pada Infografis berjudul Transportasi Umum Jakarta dari Masa ke Masa oleh Kompas Data

(sumber: https://www.youtube.com/watch?v=ZYWBn-jPk6w diakses pada 15 Agustus 2018)

Seperti yang diketahui bahwa Kompas memiliki corporate color biru pada logonya, maka ketika Kompas membuat infografis pada gambar 4 diatas, identitas warna khasnya tetap digunakan. Meski begitu, tidak semua tampilan frame berwarna biru.

Pada gambar 5 di bawah ini, konsep Pemilihan warna juga seringkali di-pertimbangkan berdasarkan target audiensnya seperti misalnya pada beberapa frame infografis produk brand Hilo Teen:
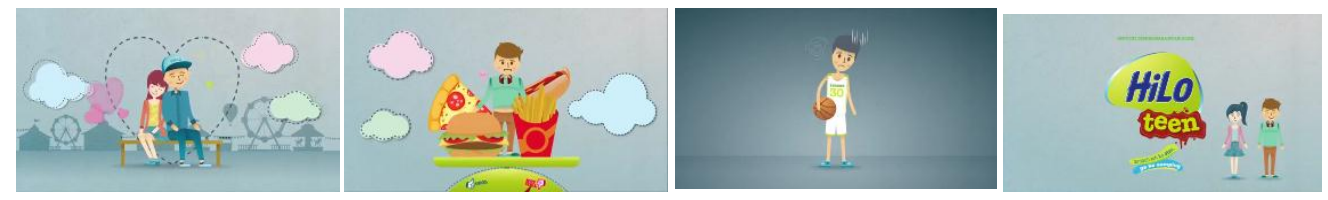
Gambar 5 Konsep dan penggunaan warna yang mempertimbangkan target audiens pada Infografis Cara Bikin Tubuh Kamu Lebih Tinggi oleh Hilo Teen

(sumber: https://www.youtube.com/watch?v=c0QJb89edRA diakses pada 15 Agustus 2018)

Penggunaan warna pada infografis Transportasi Umum Jakarta dari Masa ke Masa oleh Kompas terlihat menarik perhatian dan mempermudah memproses informasi dari cara bagaimana membeda-kan kontennya melalui perbedaan warna figure (objek) dan ground (latar belakang) setiap jenis kendaraan seperti pada gambar dibawah ini:
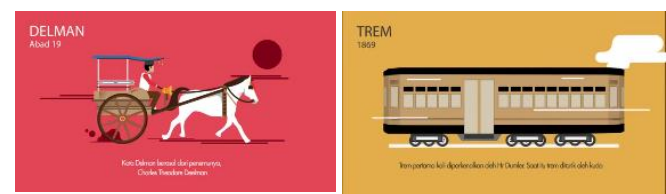

Gambar 6 Penggunaan berbeda un

(sumber: https://www.youtube.com/watch?v=ZYWBn-jPk6w diakses pada 15 Agustus 2018)

Pada Infografis di bawah ini, penerapan warna biru dan jingga yang hampir selalu ada pada tiap frame dapat menciptakan kesatuan:
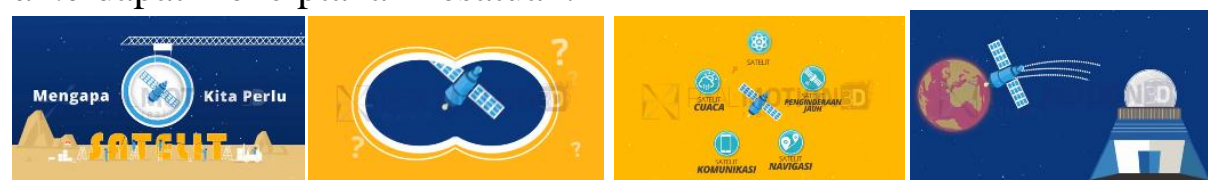

Gambar 7 Penggunaan warna berulang menciptakan kesatuan pada Infografis Satelit oleh LAPAN

(sumber: https://www.youtube.com/watch?v=xPPoK2cpptc diakses pada 15 Agustus 2018)

Penggunaan warna dalam infografis di bawah ini nampaknya berkaitan dengan kesan yang ingin ditampilkan yaitu dengan penggunaan dominasi warna merah hampir disetiap framenya. Merah bermakna negatif untuk menampilkan citra bahaya korupsi:

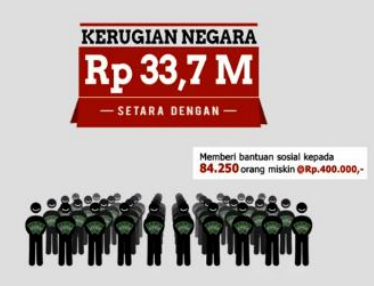

Gambar 8 konsep penggunaan warna merah untuk menghasilkan kesan negatif dan bahaya pada Infografis Lawan Korupsi oleh Indonesia Corruption Watch

(sumber: https://www.youtube.com/watch?v=KBQsblno2jk diakses pada 15 Agustus 2018)

Penggunaan warna dalam infografis juga bermaksud untuk me-nekankan informasi atau pesan tertentu seperti pada gambar dibawah ini dimana merah diantara nuansa warna hijau menonjolkan objek tertentu :

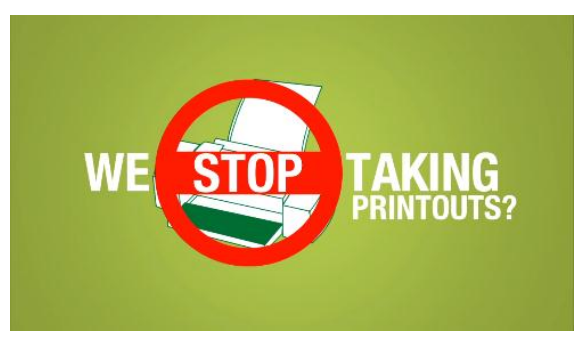

Gambar 9 penekanan melalui warna frame pada Infografis Paper to Save Forests oleh Cheil India (sumber: https://www.youtube.com/watch?v=jHQGyMBtE9Y diakses pada 15 Agustus 2018) 
Dari 20 infografis yang diamati diperoleh temuan mengenai kombinasi warna kontras yang digunakan sebagai berikut: pertama, sebagian kecil infografis menggunakan kombinasi warna kontras dengan banyak variasi warna cerah dalam setiap frame-nya tanpa adanya maksud dan konsep tertentu melainkan nampaknya secara teknis saja dalam penggunaan warnanya, kemudian sebagian besar infografis lainnya nampaknya memiliki maksud tertentu dalam penggunaan warnanya.

Penyajian informasi melalui infografis seperti halnya media lainnya didapat adanya kombinasi warna kontras untuk membedakan antara figure dan ground. Figure atau objek dapat berupa gambar dan atau tulisan, sedangkan ground atau latar belakang dapat berupa ilustrasi environment atau grafis abstrak ataupun bidang polos dan bidang bergradasi. Elemen warna pada semua infografis dibuat dalam kombinasi kontras seperti yang bisa dilihat pada gambar 10-14, agar informasinya terlihat jelas dilihat oleh mata. Kontras antara figure dengan ground diraih dengan cara: 1) Kontras nilai (value) (gambar 10 dan 11) terang gelapnya warna. Misalnya jika figure berupa gambar berwarna terang maka ground yakni latar belakangnya berwarna gelap, dan sebaliknya. Begitu juga dengan figure yang berupa huruf berwarna terang (seringkali mengguna-kan putih), maka ground berupa latar belakang baik polos ataupun ilustrasi latar belakangnya bernuansa gelap; 2) Kontras saturasi (gambar 12 dan 13), yakni cerah suramnya warna. Untuk menghasilkan kontras saturasi, seringkali digunakan warna netral yaitu cokelat, abu-abu, dan cream sebagai ground. 3) kontras hue (gambar 14), yakni menggunakan kombinasi warna yang sama dalam posisinya di lingkaran warna misalnya sama-sama cerah namun ber-lainan. Seperti contohnya warna kuning, hijau, merah, biru, ungu dalam satu frame.
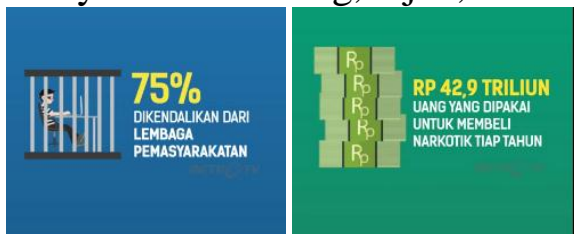

Gambar 10 kontras nilai warna antara teks dengan latar belakangnya pada Infografis Tentang Narkoba oleh Metro TV

(sumber: https://www.youtube.com/watch?v=qTICfCYFJb8 diakses pada 15 Agustus 2018)

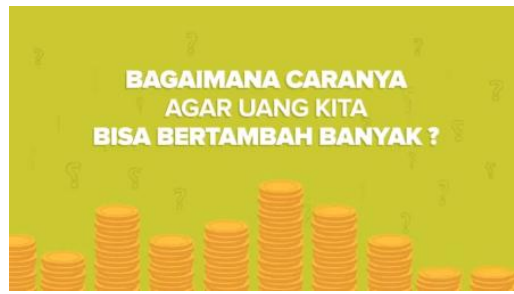

Gambar 11 kontras nilai warna antara teks dengan latar belakangnya pada Infografis Bareksa oleh Bareksa.com (sumber: https://www.youtube.com/watch?v=cXyiC5hynuo diakses pada 15 Agustus 2018)

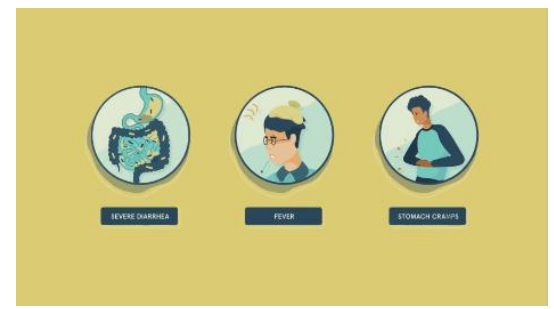

Gambar 12 kontras saturasi warna antara gambar ikon figure dengan ground pada Infografis Shigella Medical Animation oleh Marler Clark The Food Safety Law Firm

(sumber: https://www.youtube.com/watch?v=1aEiF2X3pLQ diakses pada 15 Agustus 2018) 
Gambar 13 kontras saturasi warna pada Infografis Global Air Traffic oleh Rightcolours,com (sumber: https://www.youtube.com/watch?v=OsPlhwA-ick diakses pada 15 Agustus 2018)

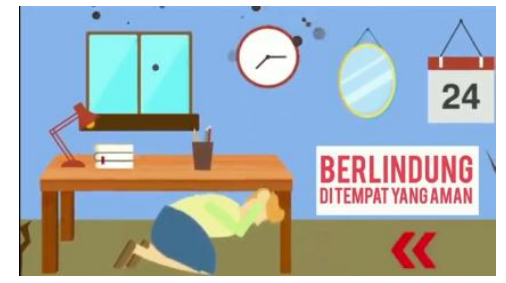

Gambar 14 kontras hue pada Infografis Kesiapsiagaan Bencana Gempa Bumi oleh kementrian Kesehatan RI (sumber: https://www.youtube.com/watch?v=wxH8tV2C8Ww diakses pada 15 Agustus 2018)

\section{Konsep dan Penggunaan Warna dalam Infografis}

Berdasarkan analisis didapat konsep dan penggunaan warna dalam infografis meliputi: 1) Warna memiliki asosiasi, simbol, dan makna yang dapat dijadikan konsep pertimbangan merancang; 2) Pertimbangan pemilihan warna dapat berupa siapa target audiens dan atau target marketnya, dan atau identitas apa yang ingin direpresentasi-kan, dan atau apa tema yang diangkat, dan atau kesan apa yang ingin ditampilkan; 3) Warna menimbulkan kemenarikan baik secara fisik maupun psikologis audiens yang melihatnya, memisahkan kategori atau antar bagian dalam konten sehingga mempermudah pemahaman, menyatukan keseluruhan bagian, memberi penekanan pada konten tertentu yang ingin ditonjolkan, menciptakan kontras antara figure (gambar maupun teks) dengan ground (latar belakang) sehingga mudah terlihat oleh audiens, dan memungkinkan untuk diingat pesan didalamnya sehingga aspek penting yaitu daya pikat, komprehensi dan retensi dapat terpenuhi.

\section{SIMPULAN}

Infografis dinamis merupakan media yang saat ini sedang diminati oleh khalayak karena sifatnya yang audio visual, aksesnya yang mudah, dan atraktif. Konsep dan penggunaan warna dalam infografis perlu dipertimbangkan dengan baik karena dapat menimbulkan 3 aspek penting infografis yakni daya tarik, komprehensi dan retensi yang memuat konsep AIDA dalam komunikasi. Pertimbangan konsep dan penggunaan warnanya mencakup siapa target audiensnya (who) yang punya preferensi terhadap warna tertentu dan siapa yang membuat infografisnya; apa pesannya, tujuannya (what) termasuk kesan yang diinginkan sehingga pemilihan warnanya berkaitan; bagaimana cara me-nyampaikannya (how) yakni secara teknis berhubungan dengan prinsip desain (kesatuan, kontras dan penekanan). Dengan begitu maka daya pikat audiens dapat diraih, pemahaman (komprehensi) audiens akan pesan yang disampaikan cenderung lebih mudah dan ber-kemungkinan untuk diingat (retensi).

\section{DAFTAR PUSTAKA}

Arifianto, P. F. (2018). Analisis visual infografis produk "Samsung Galaxy Note Edge". Aksa Jurnal Komunikasi Visual, 1 (2) hlm. 118-132. 
Dur, B. U. (2014). Data visualization and infographics in visual communication design education at the age of information. Journal of Arts and Humanities (JAH), 3 (5) hlm. 39-50.

Saptodewo, F. (2014). Desain infografis sebagai penyajian data menarik. Jurnal Desain,1 (3) hlm. 193-198.

Soewignjo, S. (2013). Seni mengatur komposisi warna digital. Yogyakarta: Taka Publisher.

Lankow, J., Ritchie, J., Crooks, R. (2014). Infografis: Kedasyatan cara bercerita visual. Jakarta: Gramedia Pustaka Utama. 